\title{
The Economic Consequences of the Doha Round for Ireland*
}

\author{
ALAN MATTHEWS AND KEITH WALSH** \\ Trinity College Dublin
}

\begin{abstract}
This paper provides a quantitative study of the economic effects of a stylised simulation of trade liberalisation for Ireland using the GTAP model. The experiment incorporates the liberalisation of agricultural, manufacturing and services trade as well as measures to improve trade facilitation. The simulation is implemented against a baseline projection of the Irish and world economy over the next decade. Overall, Ireland's welfare will increase as a result of further trade liberalisation, with particularly strong gains from services liberalisation. The industrial liberalisation scenario also generates positive gains to Ireland, while agricultural liberalisation has a slightly negative effect on the overall economy.
\end{abstract}

\section{INTRODUCTION}

$\mathrm{T}$ he Doha Round of World Trade Organisation (WTO) trade negotiations was launched in Qatar in November 2001. A successful outcome to this Round would have long-term effects on all countries involved. This paper examines the consequences of further trade liberalisation on the Irish

*This paper is based on research by the authors commissioned by Forfás. We are grateful for comments and suggestions from Forfás; the Department of Enterprise, Trade and Employment; the Department of Agriculture and Food; an anonymous reviewer; M. Ivanic, J.C. Bureau, and seminar participants at the authors' presentations in Trinity College and at the Nineteenth Annual Conference of the Irish Economic Association. The views expressed in this paper remain the responsibility of the authors and should not be taken to reflect the views of any of the mentioned organisations. Any remaining errors are our own.

Walsh gratefully acknowledges the financial support of the Institute for International Integration Studies and the Irish Research Council for the Humanities and Social Sciences.

*Contact: Keith Walsh, IIIS, Arts Building, Trinity College, Dublin 2, Ireland. Email: kwalsh2@tcd.ie. 
economy, although the nature of the model used means that Ireland is not seen in isolation, rather as an interdependent part of the world economy.

A computable general equilibrium (CGE) model is used to quantify the potential outcomes of Doha. The model used in this study, the Global Trade Analysis Project (GTAP) model and database, is well suited for modelling the impact of changes in the world trading system. The welfare impact of the trade liberalisation scenarios for each country is calculated as the equivalent variation in income. This measures the welfare change resulting from liberalisation in monetary terms (2001 US dollars) and as a percentage of GDP.

The base year of the latest version of the GTAP database is 2001. Even if WTO negotiations reach a successful conclusion in the near future, the timespan for implementation and the impact of reforms will stretch over a number of years. With this in mind, the base data are projected forward to 2014 incorporating the effects of policy changes already decided to allow more realistic modelling of the effects of any agreement. The simulation of the trade liberalisation scenarios is then implemented by introducing shocks to this baseline.

Given the preferential access which Ireland enjoys to other EU country markets as a member of the EU, the effects of further liberalisation of world trade are ambiguous. Liberalisation leads to an erosion of these preferential benefits which are particularly important in the case of agricultural trade. Hence the value of an empirical study to attempt to quantify the overall impact of a successful Doha Round on Ireland.

This paper is structured as follows. The next section describes the GTAP model and database and the process of projecting the world and Irish economy forward to 2014 and the structural changes that result. Sections III and IV outline the trade liberalisation scenario simulated in this paper and the results of the simulation. Section V presents the conclusions.

\section{METHODOLOGY}

\subsection{The Global Trade Analysis Project (GTAP) Model and Database}

The empirical work undertaken in this paper employs the CGE model and database known as GTAP. This type of model is a powerful tool enabling quantitative analysis of trade issues. CGE models divide the economy into production and consumption sectors and model them collectively. Sectors are explicitly linked through input-output relationships as well as through competition for resources in capital and labour markets. Because CGE models emphasise the impact of reallocating resources across sectors of an economy, 
they are good tools for identifying winners and losers under a policy change. GTAP in particular, with its wide country coverage and extensive database, is designed for precisely this task.

The standard GTAP model is a one period, multi-regional, CGE model. All markets in the model are perfectly competitive and exhibit constant returns to scale. The primary reference for information on the model is Hertel (1997) and the GTAP website. ${ }^{1}$ The Armington (1969) assumption is used to differentiate between homogenous commodities from different regions. The construction and calibration of the database is documented in Dimaranan and McDougall (2005).

\subsection{Model Closure and Aggregation}

A standard general equilibrium closure is used in all simulations in this paper. This implies all prices (except the numeraire), 2 regional incomes and quantities of producible commodities are determined endogenously. Tax (or subsidy) rates, technology and factor endowments are exogenously fixed. A medium-term closure is assumed. Labour and capital are assumed to be perfectly mobile between sectors. Land and natural resources are imperfectly mobile (or sluggish) between sectors. No factor endowments are mobile between regions and all are assumed to be fully employed within regions (there is no unemployment of labour or capital). In terms of macroeconomic closure, investment is savings driven and the current balance is assumed to be exogenous.

In this paper, Ireland is distinguished as a separate region, allowing for the discussion of scenario outcomes at both national and global levels. The three largest EU economies as well as the US, Canada, China and India are also individually represented. Nine agrifood sectors have been distinguished, consisting both of primary agriculture and processed products. There are also nine manufacturing industries (including electronics, textiles and chemical products sectors separately distinguished) and five service sectors. Table A1 in the Appendix shows the full regional and sectoral aggregation chosen in this paper. ${ }^{3}$

\subsection{Construction of the Baseline 2001 - 2014}

The base year of the current version 6.0 of the GTAP database is 2001 . Since then, a number of important trade policy developments have taken

1 GTAP website: www.gtap.org.

2 Because all prices are endogenous in a CGE model, one price (or price index) must be chosen as a numeraire in which to express relative price changes. In this closure, the numeraire is a composite world price index of primary factors.

3 Appendix is available online at www.esr.ie 
place. Also, even if WTO negotiations reach a successful conclusion in the near future, the time-span for implementation and impact of reforms will stretch over a number of years. With this in mind, the base data are projected forward until 2014 to allow more realistic modelling of the effects of any agreement.

The construction of this baseline is undertaken by running a presimulation experiment, the outcome of which is used as a baseline against which to compare the results of the trade liberalisation scenarios implemented in the study. The construction of the baseline is divided into two components. First, policy changes, both events that have already occurred since 2001 and those that are expected to occur in the future, are implemented to create a more realistic policy landscape. Second, macroeconomic projections are used to simulate the expected changes to the world economy between the dates in question.

The structural changes to the world economy included in this baseline are: the accession of the People's Republic of China to the WTO; the Agenda 2000 and Mid-term Review reforms of the CAP; the accession of twelve central and eastern European Countries to the EU; the full implementation of the Everything-But-Arms (EBA) Agreement between the EU and fifty of the world's least developed countries (EC, 2001); and the elimination of MultiFibre Agreement textile quotas as foreseen under the WTO Agreement on Textiles and Clothing. We also assume that Russia joins the WTO during the baseline period. The terms of accession are not specifically modelled, but Russia is assumed to participate in the liberalisation scenarios based on its tariff structure in 2001.4

The second phase in constructing the baseline to 2014 is to shock factor endowments in the model following the approach of Walmsley et al. (2000). These shocks are based on forecasts of factor growth rates over the baseline period. GDP, skilled and unskilled labour, population and capital stock in each region are shocked. The main source is Brockmeier and Salamon (2003) with additional data from Jensen and Frandsen (2003). For Ireland, data from the Economic and Social Research Institute's (2003) Medium-Term Review 2003-2010 have been used to further augment the forecasts. 5

The initial pre-simulation experiment suggested an unrealistically high growth of agricultural production in the EU, evaluated on the basis of expert opinion. In the baseline represented here, the growth of primary agricultural sectors has been constrained to target the growth rates expected (in the absence of policy change) in the most recent European Commission (2004) forecast of the likely market balance for agricultural products up to 2014. The

4 The way these policy changes are modelled is explained in greater detail in Matthews and Walsh (2005).

5 See Matthews and Walsh (2005) for the details of these factor endowment shocks. 
same growth rates were applied to each of the separate EU countries and regions distinguished in the model database.

\subsection{The EU Agricultural Budget Module}

In the standard GTAP model there is no direct link between tax revenue and government expenditure and there is no explicit representation of the EU budget. Agricultural subsidies (direct payments, input and output subsidies, market price support and export subsidies) in Ireland are assumed entirely financed through national sources, and there are no intra-European revenue or expenditure flows. This underestimates the negative impact of reforms which lower market prices and thus the inflow of CAP funds for a net exporting country in the EU.

To accurately model shocks such as enlargement or, at a later stage, to simulate the effects of trade liberalisation within a regional union such as the EU, the standard GTAP model is extended to incorporate an EU agricultural budget module based on the approach of Brockmeier (2003). This is accomplished via the addition of a new social accounting matrix that moves the EAGGF revenues and expenditures from member countries or regions to the EU budget. The EU collects 75 per cent of import tariff revenues from agents in the model and a GDP tax is levied on the member regions. This tax is determined endogenously to ensure the overall EU agricultural budget is balanced and it thus approximates both the VAT and GDP elements of revenue that accrue to the EU. The difference between revenues and expenditures of each member state is the net transfer to that region arising from the operation of the CAP. The sum of the net transfers of each region is zero to ensure that the overall agricultural budget balances. To avoid misunderstanding, it should be stressed that what is being modelled here is the EU agricultural budget, and not the full EU budget. Structural fund contributions, for example, are excluded. This should be borne in mind when interpreting the budget figures later in this paper.

\subsection{The Irish Economy in 2014}

This section describes the structure of the Irish economy in 2014 following the updating of the baseline as described in the previous section. The impact of WTO liberalisation will be determined by both the production and consumption structure of the economy and by the structure of protection assumed in the baseline in that year, rather than the economic and protection structures in 2001. It is a stylised representation of the Irish economy, and is not intended to capture detailed projections of individual sectors. 
The growth rate assumed for Ireland over the baseline period is greater than for the other EU countries. Between 2001 and 2014, GDP increases by 80 per cent, capital more than doubles, and the population and labour force increase by between 7 and 10 per cent.

Table 1 shows the structure of the Irish economy, including trade flows, output and domestic consumption, before and after the changes described in the section above are implemented, providing a baseline against which to compare the results of the simulations to follow. The importance of intra-EU trade to Ireland is a key factor underlying many of these results, hence the values for Ireland of intra-EU and extra-EU trade are indicated. 6

All non-agricultural sectors expand in line with the projected overall growth of the economy over the period. As noted in Section 2.3, the growth in the primary agricultural sectors, apart from sugar and raw milk, is constrained to meet forecasts for output growth in the EU as a whole. Output of sugar and raw milk is assumed constrained by quota. Domestic consumption of all commodities, except for other livestock, increases, in particular chemical and petroleum products and other private services.

At a more aggregated level the growth of output in agriculture trails far behind that in industry and services. As incomes increase and a region becomes richer, consumption tends to shift from primary commodities to industrial goods and services. In the case of Ireland in 2014, the increase in industrial output compared with 2001 is particularly strong, reflecting the open, export-oriented nature of the economy. The increase in industrial output is driven by an increase in demand for Irish exports.

The levels of trade protection applied to Irish imports and exports in 2001 and 2014 by industry are shown in Appendix Table A2.7 The data are calculated as the ratio of tariff revenue collected to the value of trade at world prices, and thus represent trade-weighted average applied tariffs by sector. 8 The calculated applied tariffs on 'All Trade' are lower than those shown for

\footnotetext{
6 The 2001 figures in Table 1 reflect those in the GTAP database. These data underestimate the degree of self-sufficiency for some agrifood sectors, for example, beef and sheepmeat and dairy products, and this caveat should be noted in interpreting the results.

${ }^{7}$ Available at www.esr.ie. Figure 1A, also available in the online appendix, shows the applied trade protection for Irish exports and imports by source and destination. The only notable changes are the elimination of barriers to trade between Ireland and the new EU members and of import tariffs levied on commodities exported from the EBA countries entering the EU. This is particularly important in the case of sugar.

8 These tariff values may be sensitive to very small volumes of trade in some sectors. Also, the method of calculating average tariffs may underestimate the degree of protection provided to Irish agriculture, to the extent that the volume of imports at world prices may represent preferential import prices rather than the 'true' world price. This is likely to be important in the case of sugar, for example, where EU import values reflect the price paid to ACP exporters that is linked to the EU producer price rather than the world price.
} 


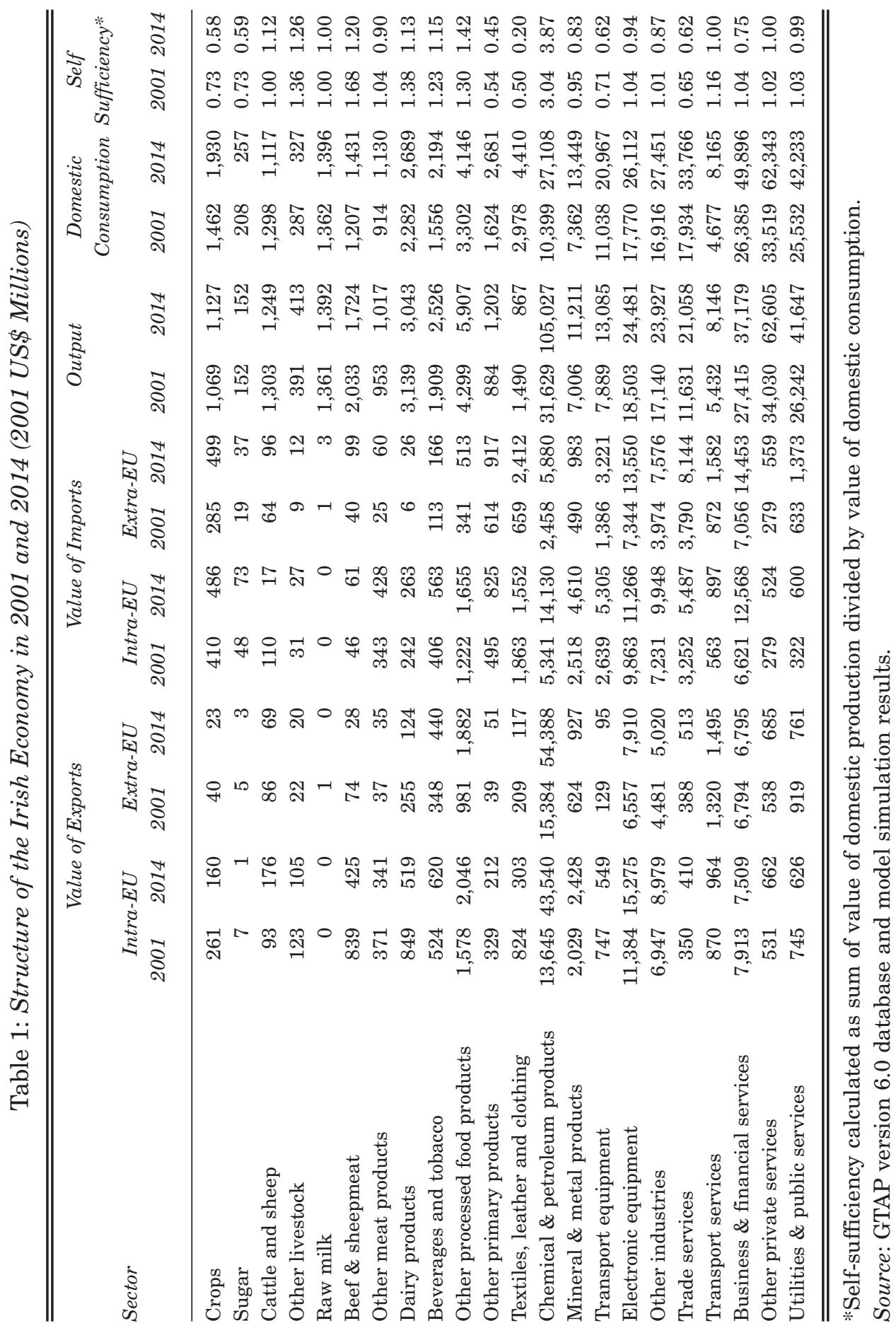


'Extra-EU Trade' as they take into account the zero tariffs that apply on intraEU trade. The dramatically higher levels of protection for some of the agrifood sectors stand out.

\section{TRADE LIBERALISATION: NEGOTIATIONS AND SIMULATIONS}

\subsection{What's Under Negotiation in the Doha Round?}

The Doha negotiations are comprehensive both in terms of their country coverage and sectoral coverage. They cover liberalisation of agricultural, manufacturing and services trade as well as clarification of WTO rules. This section outlines some of the main issues under discussion in these areas. The actual trade liberalisation simulation implemented is then described in Section 3.2.

Following the near collapse of the Doha Round at the Fifth WTO Ministerial Council in Cancún in September 2003, a Framework was agreed in July 2004 that provides a structure for negotiations towards a final agreement. However, as it contains few specific figures or targets, a stylised simulation of further liberalisation is constructed. This does not seek to approximate any particular negotiation modalities likely to emerge from WTO talks. Rather it examines the effects of broad liberalisation measures.

\subsubsection{Agricultural Trade Liberalisation}

The draft modalities on agricultural products agreed in July 2004 do not include specific targets for the cuts in two of the pillars of the Agreement on Agriculture: market access and domestic support. ${ }^{9}$ On market access, import tariffs are to be reduced on a tiered basis such that those members with higher tariff levels will implement the largest cuts. The number of tiers, the depth of the reduction, the placement of commodities and regions in tiers and the treatment of sensitive products have not yet been agreed.

On domestic support, the only firm commitment contained in the Framework is the agreement that overall trade distorting support will not exceed 80 per cent of its current level by the end of the first year. This includes final bound AMS (aggregate measure of support, the most trade distorting form of support), the permitted de minimis levels and permitted blue box levels, with future reductions to be based on a tiered formula implying greater reductions for those countries that maintain the highest levels of support.

9 See http://www.wto.org/english/thewto e/whatis e/tif e/agrm3 e.htm for an explanation of technical terms and an overview of agricultural trade negotiations in the WTO. 
For the third pillar of the Agreement on Agriculture, export competition, the July Framework contains a commitment to fully phase out the use of export subsidies for agricultural products.

\subsubsection{Manufacturing Trade Liberalisation}

The July Framework text on non-agricultural market access (NAMA) contains few details. WTO members have agreed that improvements in nonagricultural market access in the Doha Round are to be based on a formula approach, with the precise details, and other issues such as the treatment of tariff escalation and tariff peaks, still the subject of negotiation.

The US and many industrialised countries are pressing for a sector-based approach. However, they face opposition from developing country groups who favour a broad tariff reduction formula with the possibility of specific sectoral arrangements only once the overall reduction formula has been agreed upon. A consensus is emerging that an agreement on NAMA will not be reached until negotiations on agriculture are nearer to conclusion with members waiting to judge the perceived level of ambition with respect to market-opening of any such agreement (ICTSD, 2005).

\subsubsection{Services Trade Liberalisation}

Given the large share of trade in services that is accounted for by FDI in services and, in particular, its importance to the Irish economy, the outcome of any agreement on services will have significant consequences for Ireland.

GTAP is lacking on two fronts in terms of trade in services. The standard model structure does not allow for foreign direct investment which is an important mode for delivery of services abroad, and the database includes no import barriers (tariff equivalents to the qualitative barriers) for service sectors. To model services liberalisation requires quantitative estimates of trade barriers. However, unlike the case of agriculture and manufacturing, in services these barriers tend be qualitative rather than quantitative in nature. Such barriers include the existence of national monopolies in service sectors, restriction of certain activities to domestic firms or regulation of the establishment and operation of foreign service providers. The difficulties in measuring non-tariff barriers and modelling trade in services are well documented (e.g., Dee and Hanslow, 2000).

This study employs estimates based on research by Francois et al. (2005) to calculate the tariff equivalents of barriers to trade in services. These are tariff equivalents for services imported by a country or region. In the case of the EU regions, they apply to both intra-EU and extra-EU trade. 10

10 See Matthews and Walsh (2005) for the full set of tariff equivalents employed in this analysis. 


\subsubsection{Trade Facilitation}

Trade facilitation is now the only one of the four so-called Singapore issues still under negotiation in the Doha Round. Bagai et al. (2004, p. 2) define trade facilitation as encompassing “... the domestic policies, institutions and infrastructure associated with the movement of goods across borders". Its importance and sensitivity were clearly illustrated in Cancún with the breakdown of negotiations due to the refusal of developing countries to accept EU proposals over the Singapore issues.

In the context of the WTO, the definition of trade facilitation is less broad. The Doha Declaration text cites fees and formalities, transit and transparency. Trade facilitation refers to the reduction in administrative barriers to the importation of goods as opposed to barriers to trade in services as discussed in the section above which fall under the auspices of the General Agreement on Trade in Services (GATS).

An agreement on trade facilitation will have to balance the desire for reductions in transactions costs with the political will and physical capacity of developing countries to achieve trade facilitation programmes. Walkenhorst and Yasui (2003) suggest that developing countries have the most scope to gain from trade facilitation as they have less efficient border procedures and because of the nature of their trade patterns (importance of primary goods and the pre-dominance of small and medium-sized firms).

\subsection{Simulation Design}

The trade liberalisation simulation is implemented using the updated database created from the baseline experiments described in the previous section. The shocks required to implement the scenario are thus implemented against this baseline featuring the Irish and global economy as projected in 2014.

The simulation is summarised in Box 1. For import tariffs, a linear cut of 50 per cent across all agricultural and manufacturing sectors is imposed, with special and differential treatment reflected in lower cuts for developing countries and the exemption of least developed countries. ${ }^{11}$

11 Industrialised countries/regions in this paper are: EU, USA, Canada, High Income Asian countries, Rest of EFTA and the Former Soviet Union. Developing countries/regions are: Mediterranean, China, India, Rest of Asia, Rest of the ACP countries, Mercosur, Rest of Latin America and Rest of the World. Least developed countries are approximated by the EBA group of countries. 
Box 1: Summary of the Trade Liberalisation Scenario

Import Tariffs: applied agricultural and manufacturing import tariffs are reduced by 50, 34 and 0 per cent for industrialised, developing and least developed countries respectively.

Export Subsidies: a global elimination of agricultural export subsidies.

Domestic Support: trade-distorting domestic support is reduced by 20 per cent in the EU and USA and by 5 per cent elsewhere.

Services: a 50 per cent reduction in the tariff equivalents of barriers to trade in services. Special and differential treatment applies to developing regions. This is not applied to intra-EU trade in services or exports from the USA to Ireland.

Trade Facilitation: modelled as a reduction in the cost of importing all agricultural and manufacturing commodities (1.5 per cent cost reduction for least developed, 1 per cent for developing and 0.5 for industrialised countries). In the case of the EU, this applies only to imports from nonmember countries.

The tariff rates in the GTAP model and database are applied rates. WTO negotiations are based on bound tariff levels. In many cases, there will be a degree of tariff overhang whereby the bound ceiling exceeds the applied rate by a considerable amount. A 50 per cent reduction in the bound rate may not translate into an equal reduction in applied rates. Implementing reductions in applied rates by 50 per cent may overestimate the gains from trade liberalisation unless the average cut in bound rates agreed in the Doha Round negotiations is substantially greater. In other words, cutting applied tariffs by 50 per cent implies agreement on a substantially larger cut in bound tariffs once the tariff overhang impact is factored in.

The liberalisation of domestic support and export subsidies follow the structure of the July Framework. Export subsidies on agricultural products are fully phased out in the simulation. Domestic support as represented in the standard GTAP model does not allow for a full analysis of overall distorting support as defined in the July Framework. Reductions in domestic support are simulated as cuts to direct payments linked to production, intermediate input subsidies and output subsidies. The reductions reflect the tiered formula approach whereby those with higher levels of trade distorting support are 
expected to implement the most substantial cuts. ${ }^{12}$ Payments decoupled from production in the EU and US are assumed to qualify for the Green Box and, therefore, are exempt from reductions. The market price support component of AMS is not explicitly modelled, but the reduction in applied tariffs may imply some reduction in this component in any case.

Services trade liberalisation is modelled as a reduction in the estimated tariff equivalents discussed in Section 3.1.1. This is modelled as a positive productivity shock to imports of service commodities entering a region, implemented by exogenously shocking the appropriate technology variable in each of the service sectors. For EU regions, it is applied only to imports from third countries. Whilst barriers to trade in services within the single market remain, they are not subject to WTO negotiations but rather they fall within the competence of the European Community. Service trade imports from the USA to Ireland are also exempted from this shock. The Irish economic landscape is dominated by multinational firms, primarily from the US, which in the main produce goods. The Irish services trade balance is distorted as a result of this with very large license and royalty payments that are not really imports per se. As these are effectively paper transactions, it is assumed that they do not face any trade barriers. While most countries will have this effect to a degree, the unusual feature of Ireland's economy justifies taking explicit account of this fact.

The simulation of an agreement on trade facilitation follows the approach of Francois et al. (2005). Improved trade facilitation is modelled as a positive technology shock to imports entering into a county or region. Based on a survey of a range of estimates of the benefits of trade facilitation, Francois et $a l$., simulate a conservative saving of 1.5 per cent in the cost of importing agricultural and manufacturing commodities. In this paper, the shock is tiered to reflect that developing countries have the greatest potential to gain from trade facilitation. In the case of the EU countries, this shock is only applied to extra-EU imports on the assumption that membership of the single market has already eliminated customs formalities between members and hence reduces the scope of possible gains from trade facilitation.

12 The same caveat, regarding differences in bound and applied tariff rates and the degree of overhang as discussed above, applies to domestic support also. Applied domestic support is cut by 20 per cent, the bound level of support and the degree of overhang is not considered. 


\section{RESULTS}

\subsection{Welfare Effects}

The global changes in welfare of the trade liberalisation experiment are presented in Table 2. The contribution of liberalisation by industrialised countries (ICs) alone to the global total is also shown. The net result is a gain for the world economy as whole of 0.30 per cent of gross domestic product (GDP). Ireland's welfare will also increase as a result of further trade liberalisation as simulated here. The total welfare effect amounts to 0.08 per cent of GDP.

Table 2: Total Welfare Effects

(Measured as Equivalent Variation in 2001 US\$ Millions and \% of GDP)

\begin{tabular}{|c|c|c|c|c|}
\hline \multirow[b]{2}{*}{ Region } & \multicolumn{2}{|c|}{ Global Liberalisation } & \multicolumn{2}{|c|}{$\begin{array}{l}\text { Industrialised Country } \\
\text { Liberalisation Only }\end{array}$} \\
\hline & $\$ M$ & $\%$ of $G D P$ & $\$ M$ & $\%$ of $G D P$ \\
\hline Ireland & 137 & 0.08 & 210 & 0.13 \\
\hline UK & 1,644 & 0.09 & 1,641 & 0.09 \\
\hline Germany & 1,203 & 0.05 & 1,228 & 0.06 \\
\hline France & 568 & 0.04 & 585 & 0.04 \\
\hline Rest EU15 & 5,977 & 0.16 & 5,271 & 0.14 \\
\hline New EU member states & 1,744 & 0.30 & 1,817 & 0.31 \\
\hline USA & 8,906 & 0.07 & 11,100 & 0.09 \\
\hline Canada & 2,073 & 0.25 & 1,933 & 0.24 \\
\hline China & 22,909 & 1.08 & 10,149 & 0.48 \\
\hline India & 6,055 & 0.87 & 1,157 & 0.17 \\
\hline EBA & 1,068 & 0.16 & $-1,430$ & -0.22 \\
\hline Mercosur & 6,164 & 0.59 & 2,277 & 0.22 \\
\hline Rest ACP & 1,890 & 1.28 & 1,002 & 0.68 \\
\hline Former Soviet Union & 2,244 & 0.33 & 2,039 & 0.30 \\
\hline High Income Asian & 24,182 & 0.40 & 20,805 & 0.35 \\
\hline Rest EFTA & 6,311 & 1.15 & 6,238 & 1.14 \\
\hline Rest Asia & 10,740 & 1.49 & 2,119 & 0.29 \\
\hline Rest Latin America & 5,242 & 0.34 & -910 & -0.06 \\
\hline Mediterranean & 5,193 & 0.31 & $-3,247$ & -0.20 \\
\hline Rest of World & 5,411 & 0.63 & 1,020 & 0.12 \\
\hline Total & 119,660 & 0.30 & 65,004 & 0.16 \\
\hline
\end{tabular}

Source: GTAP model simulation results.

The decomposition of the welfare results for Ireland is shown in Table 3. Allocative efficiency effects and technological improvements drive the positive welfare result. The latter are due to the exogenous shocks introduced to the model in order to simulate trade liberalisation in services and trade 
facilitation. The investment and savings price effect is a terms of trade effect for the capital account.

Table 3: Welfare Effects for Ireland

(Measured as Equivalent Variation in 2001 US\$ Millions)

\begin{tabular}{lc}
\hline \hline Welfare Change & US\$ Millions \\
\hline Total & 132 \\
\hline Allocative Efficiency Effect & 306 \\
Technology Effect & 360 \\
Terms of Trade Effect & -511 \\
Investment and Savings Price Effect & 154 \\
EU Budgetary Effect & -177 \\
\hline Agriculture & -44 \\
Domestic support reductions - EU and USA & 2 \\
Domestic support reductions - Rest of World & 1 \\
Tariff Reductions - Industrialised Countries & 90 \\
Tariff Reductions - Developing Countries & 19 \\
Export Subsidies Abolished & 34 \\
EU Budgetary Effect & -190 \\
Manufacturing & 85 \\
Tariff Reductions - Industrialised Countries & 58 \\
Tariff Reductions - Developing Countries & 9 \\
EU Budgetary Effect & 18 \\
Services & 196 \\
Tariff Reductions - Industrialised Countries & 179 \\
Tariff Reductions - Developing Countries & 17 \\
EU Budgetary Effect & 0 \\
Trade Facilitation & -100 \\
Trade Facilitation - Industrialised Countries & -53 \\
Trade Facilitation - Developing Countries & \\
EU Budgetary Effect & \\
\hline \hline Source: GTAP model simutan res. & \\
\hline
\end{tabular}

Source: GTAP model simulation results.

Allocative efficiency gains arise when distortions such as domestic support and import tariffs are reduced or eliminated, as this allows the market to move closer to its competitive equilibrium and reduces the efficiency losses associated with any tax or subsidy. The allocative effects stem mainly from agriculture, reflecting the high levels of protection for agricultural sectors in the 2014 baseline. 
The terms of trade effect is negative for Ireland. The reduction of export subsidies in agriculture and increased trade facilitation both contribute to a fall in export prices relative to import prices. For a small, export oriented economy like Ireland this results in a loss as Irish producers receive a lower price for their goods on the world market relative to the cost of what they buy. In addition, given the high degree of Irish trade destined for EU markets, the erosion of preferential access to EU markets leads to some welfare losses for Irish producers.

Table 3 also shows the welfare effects for Ireland decomposed by liberalisation in agriculture, manufacturing, services and trade facilitation. The results indicate that reductions in barriers to services trade will generate particularly strong gains from services liberalisation. The industrial liberalisation scenario also generates positive gains to Ireland, while agricultural liberalisation and trade facilitation have slightly negative welfare effects.

The decomposition for agricultural trade liberalisation needs to be interpreted in the light of the way the model is designed. Overall, Ireland experiences a slight negative loss in terms of GDP. The largest effect is the effect on Ireland's contribution to the EU budget. This result arises because the gain from improved allocative efficiency is offset by the reduction in net transfers from the EU agricultural budget as well as by a negative terms of trade effect.

As noted above, in the GTAP model CAP support instruments are assumed to be financed domestically, rather than by the EU, hence all allocative efficiency gains are captured by the country in question. The integration of the EU agricultural budget module described in Section 2.4 allows the calculation of the effect of changes in budgetary flows resulting from the liberalisation scenario. Prior to the simulation in 2014 Ireland is a net recipient of EU funds. The effect of liberalising agricultural trade alone (not considering liberalisation in manufacturing and services or trade facilitation) is to reduce the size of the net transfer to Ireland by $\$ 190$ million. The elimination of export subsidies implies that Irish producers no longer receive support to sell exports to third countries. However, as the majority of domestic support in the EU is decoupled in 2014, there is little change in budget revenues and expenditure related to direct payments.

Table 3 shows the Irish economy gains by $\$ 85$ million $(0.05$ per cent of GDP) from further trade liberalisation in industrial goods. This is close to the overall gain for the world economy from this simulation and much greater in relative size compared to other EU regions. The gain arises mostly from liberalisation among ICs. This result for Ireland is not typical of those for ICs. In general, ICs benefit more from liberalisation by the developing countries 
(DCs), as this allows them access to markets in regions previously protected by high tariffs and they do not incur the terms of trade losses they suffer in the case of IC liberalisation.

Table 4 presents an alternative decomposition of the welfare effects on Ireland of liberalising tariffs on manufacturing commodities. 13 Liberalisation of tariffs on trade between Ireland and the rest of the EU has zero effect as these tariffs are already set to zero (Subtotals 1 and 3 in Table 4). The welfare gains to Ireland from this simulation are generated by the reduction of barriers to import of goods from third country regions to Ireland and opening of those markets to Irish exporters (Subtotals 2 and 4). Subtotal 2 is the main source of the gains in allocative efficiency reported in Table 3. Ireland suffers a welfare loss from the liberalisation of trade between the rest of the EU and third countries as indicated in the final three subtotals in Table 4. This is driven by lower cost goods from third countries replacing some Irish exports to the rest of the EU and to other third countries. Irish exports to the EU fall across all manufacturing sectors. However, overall industrial exports from Ireland increase in value terms by approximately $\$ 200$ million.

Table 4: Welfare Effects on Ireland - Manufacturing Tariff Liberalisation Only (2001 US\$ Millions)

\begin{tabular}{lc}
\hline \hline Breakdown of Tariff Reductions & Welfare \\
\hline Reduction of tariffs on manufacturing goods from Rest of EU to Ireland & 0 \\
Reduction of tariffs on manufacturing goods from Third Countries & 88 \\
$\quad$ to Ireland & 0 \\
Reduction of tariffs on manufacturing goods from Ireland to Rest of EU & \\
$\quad \begin{array}{l}\text { Reduction of tariffs on manufacturing goods from Ireland to } \\
\quad \text { Third Countries }\end{array}$ & 676 \\
$\begin{array}{l}\text { Reduction of tariffs on manufacturing goods from Rest of EU to } \\
\quad \text { Third Countries }\end{array}$ & -269 \\
$\quad$ Reduction of tariffs on manufacturing goods from Third Countries to & -138 \\
$\quad$ Rest of EU & -290 \\
$\quad$ Theduction of tariffs on manufacturing goods from Third Countries to & 67 \\
\hline Total & \\
\hline \hline
\end{tabular}

Source: GTAP model simulation results.

13 A feature in the software package used to implement the GTAP model allows for the results of any particular shock in a simulation to be decomposed into parts known as "subtotals". The result of a shock specified as a subtotal as part of larger simulation is equivalent to the result of implementing the same shock individually. See Harrison et al. (1999) for more detailed discussion of the decomposition of results and the subtotal feature. 
The reduction of import tariffs in this simulation causes a fall in world prices that impacts negatively on net-exporters of manufacturing commodities. 14 Because expenditure on imports increases, countries must export more to pay for these imports and this drives down the price of export goods. Whilst this result is consistent across all countries, there is a second terms of trade effect at work. Due to the large share of Irish exports destined for EU markets, the fall in Irish export prices is lower than the fall of other EU countries. As much of Ireland's trade is with other EU countries, the reduction of import tariffs following WTO liberalisation does not lead to as substantial an increase in imports into Ireland as faced by other countries. The pressure on Irish exporters to lower prices and so increase exports is therefore also less relative to other countries that must raise the level of their exports to maintain their trade balance. EU members that trade more with third countries, usually ICs, face a greater terms of trade loss because a larger share of their exports face lower world prices in this simulation. However, as Table 4 shows, there are strong benefits to Ireland from third country liberalisation as it allows Irish exporters to find new markets for goods pushed out of EU markets.

The Irish economy gains strongly from further liberalisation of services trade. As Table 3 indicates, the welfare gains for Ireland arise almost entirely from trade liberalisation by ICs. Due to the nature of the shock, a productivity increase to imports of service sectors to reflect a reduction in non-tariff barriers, it is expected that imports of services would increase. There are also gains to Irish exporters who, despite being pushed out of some EU markets by imports from third countries, are able to increase exports to other ICs and DCs.

The change in imports by source shows a consistent pattern of increased imports into Ireland from all non-EU regions in most sectors. As intra-EU trade was exempt from this liberalisation, imports of services from other EU regions are less competitive due to the shock. The growth in imports from DCs slightly exceeds those from the other ICs. On average, the tariff equivalents of barriers to trade in services were higher for DCs, therefore, allowing for a larger relative impact on this group of countries and their exports. The dominance of the gains from IC liberalisation is due to efficiency gains achieved from replacing imports from the rest of the EU with relatively cheaper services from other sources.

\footnotetext{
14 Statements about price changes arising from a simulation must be interpreted in the context of the model closure. The numeraire is a composite world price index of primary factors. Thus, a reduction in world import prices relative to this fixed basket of factor prices implies a real increase in wages (factor returns).
} 
Measures to further trade facilitation generate a negative welfare change for Ireland when implemented by ICs and DCs (Table 3). This result is in line with most other EU regions. The welfare change arising from IC or DC trade facilitation is markedly different.

Trade facilitation is modelled as a cost saving on imports into a region. It is a productivity shock and this generates positive welfare effects for Ireland when implemented in the IC region (including by Ireland itself). When DC liberalisation occurs there is a term of trade loss, due to lower export prices received by Irish producers. This arises because of the greater competition in export markets as DCs strive to increase their exports to balance the increase in imports from the trade facilitation shock.

Measures to improve trade facilitation when implemented by Ireland generate welfare gains due to the allocative efficiency gains from reducing the costs of imports into Ireland. In the case of the IC trade facilitation, this gain counters the terms of trade loss. In the DC subtotal, however, the terms of trade loss is not compensated by increased trade efficiency at home, thus Ireland experiences a negative welfare effect. That intra-EU trade, and thus a large share of Irish trade, is excluded from the positive productivity shock exacerbates the impact of the adverse terms of trade effect for Ireland.

\subsection{Sectoral Effects}

The changes at a sectoral level in Ireland arising from the trade liberalisation simulation can be seen in Table 5.15 In agriculture, whilst the market price of all commodities falls, the effects on agricultural sectors in Ireland are varied. There are large drops in production of cattle and sheep (-9.6 per cent) and in the output of the beef and sheepmeat processing sector (-15.3 per cent). Imports of beef and sheepmeat, as well as sugar, increase as tariffs on imports are reduced. Exports of beef and sheepmeat, other meat products and dairy products fall. There is a strong switch in export destinations from non-EU to EU markets (or, in the case of beef and sheepmeat, a much greater fall in exports to non-EU markets than to EU markets).

The effect of liberalisation on industrial goods is mixed. Overall, the changes in output in manufacturing sectors are quite small. In value terms, the largest reductions are in transport equipment and electronic equipment although they are small in percentage terms (1.56 per cent and 0.62 per cent falls). There is a sharper percentage fall in the output of the textiles and

15 The change in market prices in Table 5 is shown relative to the change in the consumer price index (CPI), rather than the numeraire of a composite of world factor prices, to give a more intuitive view of the results at the sectoral level in Ireland. 


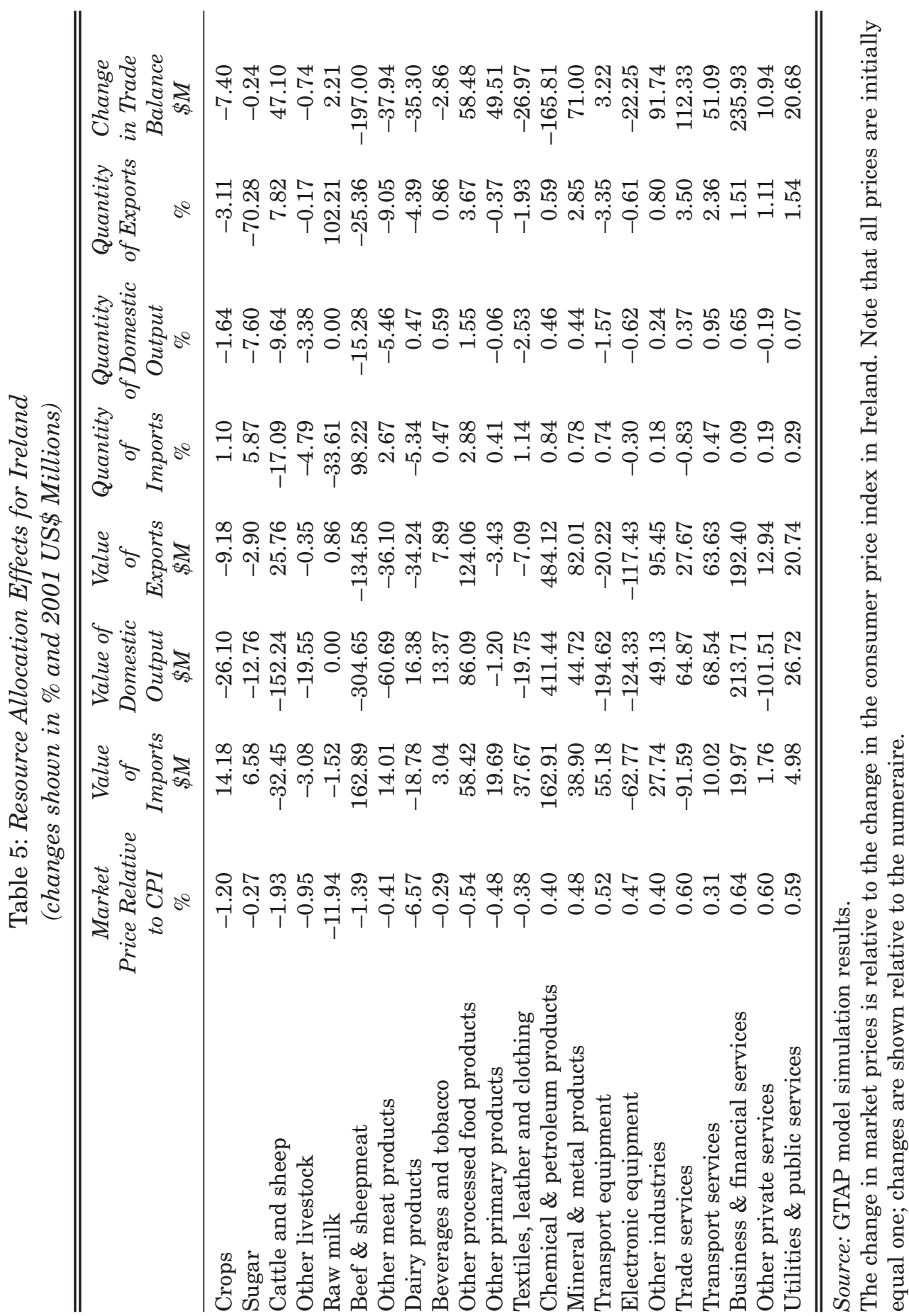


clothing sector. However, output increases in the chemicals and petroleum products $(0.46$ per cent) and mineral and metal products sectors $(0.44$ per cent).

In all of the industrial sectors in which output expands, the additional output is to supply increased demand for Irish exports from other ICs and DCs. However, there are some decreases in exports to the rest of the EU. The change in imports of manufacturing goods into Ireland shows a similar picture with large increases from other ICs and DCs reflecting lower barriers to imports from these countries, although it should be noted in value terms these changes are lower than those for exports.

Chemical and petroleum products and electronic equipment account for approximately 50 per cent and 25 per cent of Irish exports of industrial goods in the 2014 pre-liberalisation baseline. The domestic output of the former increases 0.46 per cent as a result of industrial trade liberalisation whereas production of the latter falls 0.62 per cent. How to explain these disparate trends? Domestic demand for both falls, as Irish producers substitute towards imported intermediates because their price decreases due to lower import tariffs. The differences in the output changes are explained by changes in export demand.

Export demand for chemical and petroleum products rises. While exports of these products to many EU markets fall, exports from this sector to the USA increase. The decrease in demand for Irish exports in the EU is due to tariff cuts on imports from third countries into the EU, resulting in Irish exports to other EU countries being displaced from some markets. However, consumers and firms in the USA are substituting towards Irish exports. This arises because the price of Irish exports into the US fall by more than the decrease in composite import prices for the US (i.e., the price of Irish exports to the US falls by more than the average for exports from other regions). This results from the applied tariff on Irish exports of chemical and petroleum products being higher initially than for many other ICs, hence a 50 per cent cut in tariffs implies a greater reduction in the price of Irish goods.

For electronic equipment, the demand for Irish exports falls. Exports to the rest of the EU decrease for the same reason as chemical and petroleum products (increased competition from third country exporters). In addition, in terms of export market shares, EU destinations are more important for electronic equipment than for chemical and petroleum products. Exports of electronic equipment to the USA also decrease. In this sector, the applied tariff rate is zero for Irish exports to the USA; there is therefore no gain from a reduction in US tariffs.

Driven by relatively strong increases in the export of services commodities, domestic production increases in trade, transport, business and 
financial services and utilities and public services. As Table 5 shows, imports also increase in all service sectors except trade services. The increase in output of most manufacturing sectors further increases demand for services. Those sectors that consume service commodities as intermediate inputs benefit from lower cost imports due to the liberalisation of services trade. This contributes to the overall positive effect for the Irish economy from services trade liberalisation.

Trade facilitation measures lead to increased domestic output in most sectors. Whilst the trade facilitation shock only applies to agricultural and manufacturing sectors, services also benefit from lower prices and costs. They can increase production in response to higher demand for services. In addition, the reduction in resource use in agriculture, due to the cuts in support provided to agricultural producers, facilitates the expansion in the output of most non-agricultural sectors.

Irish exports to non-EU regions increase for nearly all sectors as a result of improved trade facilitation measures (only extra-EU trade was subject to the facilitation shock in this scenario). Whilst in agricultural and manufacturing sectors there is some substitution among imports from EU regions to non-EU due to the decrease in their price, in services there is an expansion of EU imports into Ireland and Irish exports to the EU.

\section{CONCLUSIONS}

This paper provides a quantitative study of the economic effects of a stylised scenario of further trade liberalisation for Ireland. The GTAP model is used to estimate the potential effects on the Irish economy of a successful conclusion to the Doha Round.

Trade liberalisation as simulated in this paper focuses on agriculture, industry, services and trade facilitation. This is implemented against a baseline projection of the Irish and world economy over the next decade. The shocks do not represent attempts to model specific modalities of the ongoing WTO negotiations, rather they are broad measures designed to generate results that will be indicative of future changes. The cuts in import tariffs and domestic supports are implemented as reductions in the applied rates, the bound rates and the degree of overhang are not considered.

Agricultural trade liberalisation has a slightly negative effect on the overall economy as does improved trade facilitation. The negative effect from agricultural trade liberalisation arises because gains in allocative efficiency from lower agricultural protection are offset by the loss of net transfers from the EU agricultural budget as export subsidies are eliminated, and by the 
reduction in the value of the preferential access to the EU market. The loss in welfare due to trade facilitation is driven by terms of trade effects from improvements in trade facilitation in other countries. Trade facilitation by Ireland itself has a positive impact on welfare.

Ireland receives strong gains from the liberalisation of services trade, in particular from liberalisation by industrialised countries. This and the increased liberalisation of industrial trade produce unambiguous gains for Irish welfare that combined are more than double the losses from agricultural liberalisation and trade facilitation. The overall economic effects for Ireland from further liberalisation are strongly positive.

These results are important in giving a fuller perspective to the WTO Doha Round negotiations from an Irish point of view. The Irish debate has concentrated on the losses from agricultural trade liberalisation, and to farmers in particular. However, there are wider interests at stake, not only in terms of potential gains from a substantial reduction in remaining manufacturing trade barriers and from liberalising services trade, but also in terms of strengthening the rules and disciplines governing trade policy actions by WTO members. Recent unilateral actions by the US in the case of steel and by many industrial countries with respect to Chinese apparel exports, as well as simmering disputes around environmental issues and food safety standards, testify to the continuing strength of protectionist forces and to the value of strong multilateral rules which protect smaller and more vulnerable countries. As a small, export-oriented economy, Ireland has benefited from the increased opening up of the world economy and the system of world trade regulated by the WTO. A successful conclusion to the Doha Round would continue this process and underpin further growth of the Irish economy.

\section{REFERENCES}

ARMINGTON, P., 1969. "A Theory of Demand for Products Distinguished by Place of Production”, IMF Staff Papers, No. 16, pp. 159-178.

BAGAI, S., R. NEWFARMER and J. WILSON, 2004. "Trade Facilitation: Using WTO Disciplines to Promote Development”, World Bank Trade Note, No. 15.

BERGIN, A., J. CULLEN, D. DUFFY, J. FITZ GERALD, I. KEARNEY and D. MCCOY, 2003. Medium-Term Review 2003-2010, Dublin: The Economic and Social Research Institute.

BROCKMEIER, M., 2003. Okonomische Auswirkkungen der EU-Osterweiterung auf den Agrar- und Ernahrungssektor, Wissenschaftsverlag Vauk Kiel KG.

BROCKMEIER, M. and P. SALAMON, 2003. WTO Agricultural Negotiations - A Key Area for the Success of the Doha Round, Braunschweig: Federal Agricultural Research Centre.

DEE, P. and K. HANSLOW, 2000. Multilateral Liberalisation of Services Trade, 
Canberra: Productivity Commission Staff Research Paper,.

DIMARANAN, B. and R. MCDOUGALL (eds.), 2005. Global Trade, Assistance, and Production: The GTAP 6 Data Base, Center for Global Trade Analysis, Purdue University.

EUROPEAN COMMISSION (EC), 2004. Prospects for Agricultural Markets and Income 2004 - 2011 for $E U$-25, available at http://europa.eu.int/comm/agriculture/ index en.htm

EUROPEAN COMMISSION (EC), 2001. Council Regulation (EC) No. 416/2001 of 28 February, Official Journal of the European Communities.

FRANCOIS, J., H. VAN MEIJL and F. VAN TONGEREN, 2005. "Trade Liberalisation in the Doha Development Round", Economic Policy, Issue 42, pp. 349-391.

HARRISON, W., M. HORRIDGE and K. PEARSON, 1999. Decomposing Simulation Results with Respect to Exogenous Shocks, IMPACT Project Working Paper, No. IP-73.

HERTEL, T. (ed.), 1997. Global Trade Analysis: Modelling and Applications, Cambridge: University Press.

ICTSD, 2005. Bridges Weekly Trade News Digest, available at http://www.ictsd.org/.

JENSEN, H. and S. FRANDSEN, 2003. "Impact of the Eastern European Accession and the 2003 Reform of the CAP", Food and Resource Economic Institute Working Paper, No. 11.

MATTHEWS, A. and K. WALSH, 2005. The Economic Consequences of the Doha Round for Ireland, Dublin: Forfás.

WALMSEY, T., B. DIMARANAN and R. MCDOUGALL, 2000. A Base Case Scenario for the Dynamic GTAP Model, available at www.gtap.org.

WALKENHORST, P. and T. YASUI, 2003. "Quantitative Assessment of the Benefits of Trade Facilitation”, OECD TD/TC/WP(2003)31/FINAL, Paris: OECD. 
03 Matthews article 2/4/06 6:47 pm Page 70 